was worn out by the wind. Near the grave a large hewed post was planted, on which was inscribed, in Indian characters, many of the warrior's heroic deeds. A small piece of ground, including the grave, flag-staff, \&c., was inclosed with a strong picket fence, in circular form, about twelve feet high. Here the body remained, as I am informed by $\mathrm{Mr}$. Jordan, until July, 1839, when it was taken away by one Dr. Turner, then residing at Lexington, Van Buren county.

[To be continued. $]$

\title{
AN ADDRESS DELIVERED BEFORE THE HAWKEYE PIONEER ASSOCIATION OF DES MOINES COUNTY, IOWA, JUNE 2D, 1858.
}

\section{BY HON. CHARLES MASON.}

\section{[CONCLUDED FROM JULY NUMBER.]}

"In July, 1838, we became a separate Territory, and not long afterwards, the surveys of the public lands in this neighborhood having been completed, the boundaries of our connties were fixed with precision. The public lands were brought into market, and we became possessed of the legal titles to our real estate. Regnlar government was soon afterwards established in the older counties, and rapidiy extended, as civilization made its way into the interior.

As illustrative of the novel uses to which it was necessary to adapt the'limited means within our reach in those early days, and of the shifts to which we were driven by the great mother of invention, I need but remind you of some of the scenes which have been witnessed within these rery walls.* The main body of this edifice has now been standing about twenty

*u Old Zion" Church. 
years. It was the first and for many years the only church building in the city of Burlington.

Whoever at the present day sits within its hallowed precincts, listening to the fervid prayer, the calm discourse, the swelling anthem or the loud hosanna, would be very erroneous in the conclusion that these were the only sounds that had ever echoed within its consecrated walls. No: other halls have wi:nessed more important and more tragical scenes, but where will you find those that could give a more variegated history of what had transpired within them?

Here was embodied, for several years, the legislative wisdom of the Territory of Iowa-the "Lower" House paradoxically occupying the hall above, and the "Upper" House, the roo:u below. From these went forth those edicts which for many a year have ruled this goodly land. Here, too, the Supreme Judicial Tribunal of the Territory held its sometime session, and the regular terms of the District Court were here convened for many a successive year. Here the rights of persons and property were adjudicated. Here the felon trembled and hoped at the prospect or an inefficient penitentiary, and here the murderer received his tinal earthly doom.

Nor is this all. With the eye of vivid recollection I now see before me the assembled patriotism of this young city, in democratic council convened, to hear the propositions brotght by the bearers of a flag of truce from a hostile camp, to discuss, in high debate, the momentous question of peace or further war with our more poweriul but not more valiant antagonist. A model war was that, and right worthy of our praise, where not one droop of hostile blood was shed; where those who won the glory paid the bills, and ever since then their hearts have inclived to peace.

Finally, here our amiable Governor once met in friendly conference, the representatives of some of the dissatistied red children ; to hear their complaints and to promise them justice. Here we listened to their native eloquence, and were afterwads treated in this very presence to the song and the war dance. The wild whoop of the savage, which had so often carried dismay and horror into many a stout heart, failed to make any 
impression upon the walls of "Old Zion," which looked on in staid gravity, and seemed fully prepared not to be suprised at anything strange thereafter.

But all these things have long since passed away. Our in stitutions, civil, political and religious, strengthened and matured by the very suocks and commotions to which they have been subjected, have at length settled down into order and quiet and propriety. Nearly twelve years since our Territory having passed through the necessary training in incipient self-government, having sufficiently organized and solidified her institutions, and having acquired the necessary amount of population, was admitted into that great sisterhood of States, which, by its moral, more than by its physical power, is now felt throughout the earth, and will at no distant day, in a greater or less degree, give law to the whole race of mankind.

There are some events which seem to increase in magnitude and importance as they recede in distance. The establishment of a new State-one that is probably destined to exist till "the last syllable of recorded time"-is of that sublime and solemn character. While that State endures its founders will become inore and more venerated. To us of the present age and country, such an event is of so common occurrence that, like the glory of the morning sun or the starry vault of mid. night, it fails to be adequately appreciated. But when the historian of the thirtieth century shall attempt to trace the rise, progress and destiny of our federal Union and its sovereign constituents, he will rank the empire builders of the present day and country high in the scale of human philanthropists and benefactors. Individually, their names may all have sunk into oblivion, but, like the invisible stars that shed their twilight glory over the milky way, the united acts of those who planted, fostered and protected the infancy of our broad State, shall glow and brighten on the page of history forever. Not that their names were written on the scrull of fame in characters of human blood; not that they had carried havoc and desolation into the peaceful homes of a neighboring people. The triumphs of peace 'will hereafter be ranked high above 
those of the most successful acts of violence and bloodshed. Those who, obeying the generous instincts, which prompt the young and ardent to brave danger for the public weal, abandoned the conforts of civilized life, and the homes of their early years, to plant the standard of civilization in the wilderness, who contended not in the exciting strife with foes of flesh and blood, but with the debilitating diseases and disheartening privations incident to a frontier life. Who, in mute, uncomplaining agony, saw the friends whom they loved as their own souls, fade and die in their arms or by their sides; who, by their sufferings, their efforts and their sacrifices, have caused to spring forth from the soil of this great State the food and comfort which make glad the hearts of millions in other lands. These are they who, in after times, will receive the meed of praise as being the heroes of peace, the genuine benefactors of the world.

And here $\mathrm{I}$ close my reflections upon the past; but from my present stand-point I cannot deny myself the pleasure of glancing for a moment in the opposite direction. The interest of this occasion arises not more from the contrast of the Present with the Past, than from that with the future.

In point of importance in the Federal circle, we now rank among the smallest of the States. The next census will show us little if any below the medium. Some of the present members of this Society will see the time when Iowa will be the fifth State in the Union in point of population, and the third, if not the second, in respect to agricultural wealth and resources. And but a few generations will pass away-a short period in the existence of a State-before our prairies shall yield their full amount of annual treasures into the garners of the husbandman, and our descendants shall exceed in number the population of Imperial Rome when she had the world at her feet. Then, with her institutions in full maturity, and her power and influence at their zenith, shall the stalwart tree retain something of the form and character which were communicated by her own hands when it was a nursling shrub. Then, and for ages afterwards, shall the institutions we have 
assisted in establishing continue to influence the destinies of this mighty State.

But le: us give our vision a wider range, and mark the promised progress of that whole country of which we form so fair a portion. It is not in her individual capacity-sovereign though she be-that the brightening destinies of our State exhibit themselves in their grandest and most interesting aspect; but it is as a member of that great social compact of sovereigns, which out of many forms but oue, that she excites our highest patriotic pride.

Since the epoch we now celebrate, the population of the United States has fully duubled; then wealth, power, and importance have augmented in a much greater ratio. Already have we the largest eommercial marine of any power on the face of the earth; with only one competitor in all the arts of peace, and $\mathrm{nith}$ a more active and enterprising people than can be found elsewhere under the sun. At the end of another quarter of a century, our numbers, judging by the past, will have doubied again-exceeding those of France or Great Britain, including all except her Asiatic dependencies; and by the commencement of another century we shall equal those of even Russia herself. Before that date the financial centre of the civilized world will have crossed the Atlantic. Our limits will include all that is of essential value in the whole of North America; our progress in science, agriculture, the useful arts, the means of locomotion, and all that gives real prosperity shall be unequalled by any other nation, and we shall stand confessedly the leading power upon the face of the whole earth.

Not that our military strength and appointments, either on the ocean or on the land, shall exceed those of any of the sovereigns of Europe; not that we are about to enter on a career of conquest, to subjugate by force our neighbors, either on the North or on the South. Such an attempt would be the extreme of folly, not to say of wickedness, and would lead us far away from the end at which we should be aiming.

Our mission is, "peace on earth and good will to all men." On that, as a foundation, our government rests. That is the 
source of all our real power and progiess. Unless urged by some great necessity, we should not deviate from that line of policy. We have but to follow the precept of the Golden Pule and the dictates of our own moral sense, to deal justly, kindly, generously, with each other and with all other na ions; to practise charity and moderation, but at the same time friendship, both at home and abroad; in order not only to confer on others, but also to secure to ourselves, the greatest possible amount of benefits-including territorial expansion, national growth, and that moral power which as greatly exceeds physical force on the score of efficacy as on that of humanity.

These will secure us eternal peace and domestic tranquility. Sectional jealousies and bickerings will soon cease to be dangerous. Foreign nations will court our friendship, and avoid wantonly to provoke our displeasure. Neighboring States and provinces will gladly seek to escape from the inconveniences of colonial dependence, or the terrors of domestic anarchy, by mingling their interests and their national existence with ours, and in this manner all we ought to desire will be cheaply obtained without the firing of a hostile gun for a century to come.

But your apprehensions have perhaps already suggested the enquiry, whetler this very expansion is not fraught with the danger of dissolution. Such an event may indeed take place, vut not in consequence of territorial enlargement. A separation would be much more likely to take place between two States than between fifty. Had the number of the States in this Union never been increased beyond their original thirteen, I very much doubt whether a separation would not have taken place before this day. The power that made us a natim has provided the means of preserving us so. The great interior States, formed since the adoption of the Constitution, are the chiet bond upon which the Union relies for its preservation at the present day. Every new acquisition increases the strength and number of those ties which hold us united. Even were there no other feelings involved than those of patriotic pride, I appeal to every heart among you whether each angmentation of territory, while it increases our common property, does not 
also increase the reluctance with which you would see a dissolution of that government which holds it in trust tor us all ; whether every advance in national power and importance does not enhance the repugnance with which you would descend from a pre-eminent to a subordinate national position.

I will venture the opinion, founded on matnre reflection, that the whole Mexican Republic might at once be admitted into this Union, if done by mutnal consent, the States and Territories placed on a footing of equality with our own, without cansing any essential disturbance or danger to our own institutions. I believe that there is sufficient vital power and vigor of constitution in our Federal system to enable it at once to to take our weaker neighbors by the hand and steady their footsteps until they shall be able to stand and to act with their own unaided strength. All that would be necessary for that purpose would be that protection against domestic insurrection which the Federal power accords, under the Constitution, to all the States of the Union. Events at no distant day may bring this question to the test of experiment. But I must return from this digression.

Such, then, is the prospect presented by the future of our Federal Government. Such the hopes which the circumstances around us justify us in indulging. We may be doomed to disappointment. You and I may live to see that glorious Union, around which so many of our fondest hopes now cluster, rent in twain or scattered in fragments. Instead of being the citizens of a central State in a confederated Republic, which is a great and growing power among the nations, we may find ourselves on the very frontier of two or more weakened and warring factions, the sport of those despots who have trembled at the consequences of our united example.

The very magnitude of this danger, while it appals us, brings with it our surest guaranty of safety. No sane man is in danger of dashing himself by daylight down the precipice which jawns in full view before him. The menaces engendered by causes of occasional irritation, are soon forgotten when the sober realties of dissolution array themselves fully before us,- 
a truth which has already been illustrated on several memorable occasions.

If there is any class in all our wide domain who, more than all others, can be relied upon as being loyal to our present constitution and government, it is the pioneers of Iowa who have giveu a State to that very Union. In their name, and in this sacred presence, I here ntter the solemn pledge that they wili ever be found standing shoulder to shoulder in defense of that great political fabric, which is partly the work of their own hands, and which they have so essentially aided to strengthen and adorn.

\section{HISTORY OF THE CONGREGATIONAL CHURCH OF DUBUQUE.}

$\triangle$ DISCOURSE DELIVERED ON SABBATH, APRIL 8,1860 , BY REV. JOHN C. HOLBROCK, PASTOR.

[CONOLUDED FROM JULY NUMBER.]

Let us now turn for a few moments from externals and review the spiritual history of this church and congregation. During the eighteen months labor of the first minister after the church was formed (Rev. Z. K. HAwLEY) there were four members added on profession and six by letter, so that, deducting dismissals, there were twenty-six on the roll at the beginning of $\mathrm{my}$ term of service. During my pastorate there has been a steady onward progress, alt.ough there have been seasons of darkness and discouragement- "fightings without and fears within." God has watered the seed sown, with showers of Divine influences and has caused His doctrine to drop as the rain and distil as the dew, and converts to spring up as willows by the water-courses. Six distinct and marked Revivals of Religion have been enjoyed in which large numbers have been turned from sin to holiness and led to cast in their lot with us. 
Copyright of Annals of Iowa is the property of State of Iowa, by \& through the State Historical Society of Iowa and its content may not be copied or emailed to multiple sites or posted to a listserv without the copyright holder's express written permission. However, users may print, download, or email articles for individual use. 